\title{
РОЛЬ УКРАЇНСЬКОЇ МОВИ ЗА ПРОФЕСІЙНИМ СПРЯМУВАННЯМ У СТАНОВЛЕННІ МАЙБУТНЬОГО ВЕТЕРИНАРА
}

У статті охарактеризовано місце украӥнської мови у становленні майбутнього спеціаліста. Здійснено спробу аналізу педагогічних умов формування професійного спілкування студентів аграрного університету на матеріалі вивчення української мови професійного спрямування.

Ключові слова: украӥнська мова за професійним спрямуванням, професійне спілкування, ветеринар.

В статье дана характеристика места украинского языка в становлении будущего специалиста. Осуществлена попытка анализа педагогических условий формирования профессионального общения студентов аграрного университета на материале изучения украинского языка профессиональной направленности.

Ключевые слова: украинский язык профессиональной направленности, профессиональное общение, ветеринар.

The article characterizes the position of the Ukrainian language in the formation of the future specialist. The attempt of pedagogical conditions analysis of professional communication formation of agrarian university students on the basis of the Ukrainian language for the professional orientation has been made.

Key words: Ukrainian language for professional orientation, professional communication, veterinarian.

Сучасний підхід до організації вищої освіти характеризується прагненням України увійти до європейського освітнього простору i зумовлений бажанням створити конкурентоспроможну розвинену економіку та сільське господарство. Цілком очевидно, що створення потужної динамічної економіки і подальше очолювання іiі належатиме, у першу чергу, представникам інженерного й аграрного корпусів країни, підготовкою кадрів якого займаються інженерні та аграрні ВНЗ. Діяльність, що базується виключно на використанні технічних знань, останніх здобутків сучасної науки, залученні новітніх високих технологій, - це об'єктивно поступальний шлях у розвитку матеріальної культури спільноти. Він призводить до зростання кризи у сфері духовних $\mathrm{i}$ гуманістичних засад сучасного суспільства. Розуміння цієї перспективи надає змогу спрогнозувати ії наслідки, а звідси - запобігти їм через гуманізацію та гуманітаризацію аграрної освіти, зокрема у сфері мови.

Питання про вплив мови на самосвідомість, світогляд та поведінку людини розглядалося неодноразово. Наявність такого впливу незаперечна, але необхідне ще й розуміння ролі мови як одного з найважливіших чинників професійної освіти. Функціонування мови в навчальному процесі вищої аграрної школи формує мовну особистість, оскільки державна мова є частиною професії.

Мовна освіта в аграрному вищому навчальному закладі посідає особливе місце. Люди, у свідомості яких мова фаху асоціюється із знаковою системою, до складу якої входять цифри, числа, різні символи, формули, інші графічні одиниці, та великою кількістю термінів, вербальну мову як знакову систему не сприймають очевидною частиною професії. Проте об'єктивно, хоч мову і відносять до систем знакових, дещо символічних, вона не відокремлюється від безпосереднього досвіду і не розташовується паралельно, а тісно переплітається з ним. Усе, з чим має справу людина, вся денотативна сфера - предмети, процеси, події - сприймаються так, як вони називаються. Вони у певній спільноті реалізуються через свою назву, в якій зосереджується весь набір національного, своєрідного, універсального.

Проблема професійного спілкування майбутніх спеціалістів є предметом дослідження фахівців різних галузей - педагогів, психологів, мовознавців, які розглядають питання професійної комунікативності. Формування навичок професійного спілкування представлено у дослідженнях (Р. Бибрих， I. Браїм, І. Васильєв， О. Гребешок， Т. Гребешок， О. Даниленко, Г. Даниленкова, Г. Керсакова, Є. Лушникова, Є. Руденський, Н. Самсонова), міжособистісної взаємодії й особистісно орієнтованого спілкування як підгрунтя фахової комунікативності (Ю. Бабанський, Б. Гершунський, А. Мудрик, Н. Обозов, Р. Шакуров та ін.).

Однак питання формування культури професійного спілкування студентів аграрних вищих навчальних закладів у процесі вивчення курсу «Українська мова (за професійним спрямуванням)» залишається ще недостатньо вивченим.

Meта статmi - визначити роль української мови за професійним спрямуванням у фаховому становленні майбутнього ветеринара.

Професійне спілкування реалізується в мовній комунікації і $є$ втіленням у мовленні форм професійної діяльності з урахуванням різних рівнів взаємодії, специфіки ситуацій, мети й завдань навчання. Професійне спілкування загалом розглядається як інтелектуальне спілкування, що грунтується на комплексі професійних знань, умінь i навичок. Формування професійного спілкування майбутніх фахівців аграрного сектору економіки неможливі без систематичної, цілеспрямованої підготовки в рамках предмета «Українська мова (за професійним спрямуванням)» (далі УМПС), введення якого до навчальної програми аграрних закладів освіти продиктувало саме життя. 
Відтак, в аграрному секторі професійне спілкування - це рівень мовленнєвої, писемної й немовленнєвої взаємодії, що дає змогу встановити адекватне міжособистісне сприйняття, розуміння й взаємодію людей у процесі трудової діяльності. Професійне спілкування безпосередньо пов'язане із інтелігентністю спеціаліста, яка визначається ступенем його прилучення до світової культури та іiі скарбниць, чому сприяють усі гуманітарні науки, і насамперед - мова.

Ідеї та положення творчої спадщини педагогів К. Ушинського, С. Русової, І. Огієнка, Г. Ващенка, В. Сухомлинського та інших дають підстави стверджувати, що мова $\epsilon$ основою психічного, фізичного, інтелектуального розвитку особистості.

Мова охоплює всі сфери життя. Вона виникла в суспільстві, обслуговує суспільство, є однією 3 найважливіших ознак суспільства i поза суспільством існувати не може. Мову називають акумулятором, інтегратором культури. Про те, що мова $є$ явищем суспільним, засвідчують ії функції: комунікативна - функція спілкування та функція формування і формулювання думки.

Незаперечним фактом є те, що функціонує єдина українська мова. Однак кожний із тих, для кого українська мова $є$ рідною, користується нею по-своєму. Мовець бере 3 неї не все, що йому вкрай необхідне і відповідає його мовним уподобанням. Іншими словами, кожного мовця характеризує власне мовлення, яке $є$ унікальним, неповторним. Отже, на думку М. Кочергана мовлення конкретно застосована мова, засоби спілкування в іiі реалізації. 3 історичного погляду мовлення первинне, а мова вторинна.

Мовлення в діловій сфері здійснюється в усній та писемній формах. Кожна 3 форм має свої особливості. У писемній формі це різновиди текстів документів, що відзначаються певним набором реквізитів, змістом, відношенням зафіксованої в них інформації до предмета, напряму діяльності.

Усне мовлення - ситуативно мотивований і ситуативно зумовлений процес. Існує три форми усного мовлення: монолог, діалог, полілог. Монолог є штучною мовленнєвою формою, справжнє своє буття мовлення знаходить лише в діалозі. Ось чому на наступних етапах навчання переслідуємо мету розвитку саме діалогічного мовлення, коли обмін репліками відбувається між двома й більшою кількістю студентів. У процесі навчального діалогу відбувається обмін ідеями. Отже, практично кожний учасник діалогічного мовлення стає творцем.

Виконання комплексу завдань для розвитку усного ділового мовлення за схемою «монолог-діалогполілог» можна розглядати як невід'ємний складник фахової та життєвої адаптації майбутніх ветеринарів, оскільки їхні комунікативні відносини в процесі навчання набувають природних, наближених до реальної діяльності форм. Функціональна модель $є$ зручним способом репрезентації явища, хоча й спрощеного та ідеалізованого, залежного як від модельованого об'єкта, так і від способу моделювання. Звичайно, відтворювати безліч робочих ситуацій в одній типізованій моделі завдання не з простих, бо відомо, що абсолютних моделей спілкування не буває.

Усі спроби моделювання мовленнєвої діяльності є лише теоретичним припущенням, проте в будьякому спілкуванні, навіть за наявністю випадкового, існують незмінні моменти, що можуть прислужитися в побудові моделі інтеракції професійного самостворювання людини.

У процесі спілкування люди здійснюють комунікацію засобом мови. За допомогою мови люди заявляють про свої потреби й інтереси, висловлюють свою думку. Спілкування - сукупність зв'язків і взаємодії індивідів, груп, спільнот, під час яких відбувається обмін інформацією, досвідом, уміннями, навичками й результатами діяльності. Найзмістовнішим, ємним і виразним засобом людського спілкування $€$ слово, мова. Уміння говорити і слухати, вести бесіду - важлива умова взаєморозуміння, перевірка істинності чи помилковості своїх думок, уявлень. Однак і «мова тіла» (погляд, жест, поза, особливості поведінки при розмові) може виявити ставлення до людини, характеризувати культуру співрозмовника.

Під час спілкування завжди відбувається обмін інформацією - комунікація. Однак спілкування й комунікація не тотожні за своїм змістом.

Комунікація (лат. communico - спілкуюсь із кимось) - смисловий та індивідуально-змістовий аспект соціальної взаємодії; обмін інформацією у різноманітних процесах соціальної взаємодії. Зміст комунікації може бути різноманітним, але це завжди повідомлення, що забезпечує досягнення певної мети. Спілкування передбачає не просто обмін інформацією, а й обмін знаннями, враженнями, почуттями та емоціями. 3 одного боку, вони швидкоплинні, з іншого, - стійко позиціонують індивіда щодо інших людей і предметів.

Люди розмовляють (користуються мовленням) не для того, щоб демонструвати своє вміння говорити, а щоб передати певну інформацію. Комунікативна компетенція містить у собі також знання мов, спілкування з людьми, навички праці в групі, володіння різними соціальними ролями. За стандартами програми УМПС студент повинен уміти представити себе, вміти поставити запитання, брати участь у дискусії, написати листа, заяву, записати анкету тощо [3, с. 124].

Людина стає особистістю тільки в процесі соціалізації, тобто спілкування, взаємодії з іншими людьми. У діяльності відбувається всебічний і цілісний розвиток особистості людини, формується їі ставлення до навколишнього світу. Тому не випадково мотивація навчання, інтерес до навчальної праці, пізнавальної діяльності, навчального предмета посі-дають провідні місця поміж факторів, що визначають продуктивність навчально-виховного процесу у вищому навчальному закладі. Мотиви - 
головні рушійні сили навчального процесу. Справжнє джерело мотивації людини знаходиться в ній самій. Ось чому вирішальне значення надається не мотивам навчання - зовнішньому тиску, а мотивам учіння - внутрішнім збуджувальним силам.

Мотивація навчально-пізнавальної діяльності складається із сукупності певних мотивів. Мотив навчально-пізнавальної діяльності - це намагання студента досягти певного рівня розвитку в навчанні та професійній діяльності, основою котрого є глибокі, міцні й різноманітні загальнонаукові та професійні знання, навички й уміння. Пізнавальна мотивація підвищує активність студентів, сприяє перебудові психічних процесів i, відповідно, має вплив на їх розвиток. Тобто основна проблема для студента в навчальному процесі - не тільки отримання високих балів (мотивація досягнення), а й система глибоких, міцних загальнонаукових і професійних знань, навичок і вмінь, всебічний і гармонійний розвиток особистості. Безперечно, мудро чинять ті педагоги, які мотивацію пізнання використовують для формування професійної мотивації та спрямованості особистості майбутнього спеціаліста, і не останню роль у цьому відіграє мовлення.

Розглядати структуру професійного спілкування необхідно в єдності іiі компонентів: мотиваційного, когнітивного, комунікативного, психологічного, етичного, рефлексивного. Оцінювати iii сформованість необхідно за зовнішніми ознаками: активністю, ініціативністю, наполегливістю студентів у процесі їхньої комунікативної діяльності, нестандартним вирішенням комунікативних ситуацій. Важливе значення має вміння обгрунтувати оптимальність вибраного рішення: аргументовані судження, толерантне ставлення до думки співрозмовника; уміння легко й швидко налагоджувати міжособистісні контакти, адекватна самооцінка результатів своєї діяльності. Культура мовлення майбутнього фахівця аграрного сектора полягає в легкому переході 3 одного стилю на інший залежно від умов і мети спілкування.

Розпізнавання справжніх мотивів діяльності партнерів для спілкування має важливе значення для розуміння їхніх конкретних дій і вчинків. Усе це дає можливість визначити не тільки стратегію, а й тактику професійного спілкування.

Мова професійного спілкування - це засіб мовного професійного спілкування. Безумовно, такі теми, як: «Українська орфографія, їі значення для правильного оформлення ділових паперів»; «Лексичний склад української літературної мови, його застосування в ділових документах»; «Українська фразеологія ділової мови, її місце в діловій документації», «Роль словників у складанні ділових паперів», «Словотвір у діловій мові» необхідні для актуалізації здобутих раніше мовних знань 3 акцентом на особливостях функціонування сучасної української літературної мови, але мета професійного спілкування - урегулювання ділових стосунків у державно-правовій та виробничопрофесійній сферах життя через організацію, стимул, контроль, реакцію; розв'язання професійних завдань через з'ясування відношень між даним і новим, бо кожна сільськогосподарська спеціальність має свої мовленнєві особливості.

Термінологія $є$ елементом наукової мови й разом із нею складником української літературної мови, відшліфованим варіантом національної мови, і належить до одного з іiі стилів. Тому на заняттях з УМПС слід приділяти увагу як офіційно-діловому стилю, так і науковому [2, с. 72]. Слід зазначити, що специфіка наукових текстів полягає в основному не в синтаксисі, який використовує синтаксис загальнолітературної мови 3 деякими обмеженнями, а в лексиці, значну частину якої складають терміни, і яка характеризується відсутністю деяких класів слів, наприклад, особових займенників - я, ти, ви. Вивчення УМПС має велике значення і в розвитку емоційної сфери студента, його інтуїтивної оцінки, творчого уявлення, асоціативного мислення та ін. Формування таких якостей надає цілісності творчому потенціалу студента, гармонізує його.

Отже, процес навчання може бути тільки у спільній діяльності викладача й студента, тобто реалізується в єдності викладання й навчання. Обсяг змісту, що передається в навчанні, збільшується під час поповнення людьми соціального досвіду. Водночас незалежно від того, великий чи малий цей обсяг, завжди в такому змістові втілюється уявлення про те, що людина повинна знати й уміти.

Сучасний педагогічний процес прагне до того, щоб необхідність у керівництві ним відпала, i випускник школи в подальшому сам розпоряджався собою, сам навчався й удосконалював себе. Розвиток системи безперервної освіти в багатьох країнах викликано не тільки вимогами виробництва, а й значною мірою прагненням людей до самовдосконалення.

Відповідно, розвиток мови та мовлення як засобу професійного самоствердження людини в сучасній професійній праці $\epsilon$ процесом складним та багатостороннім. Щоб підготувати висококваліфікованого фахівця, викладач повинен брати до уваги закономірні зв’язки як результат науково-педагогічних досліджень. Маючи намір увійти в загальносвітовий економічний та політичний простори, Українська держава має дбати передовсім про розвиток власної мови, щоб за її допомогою увійти в ці світові структури відповідно виробивши потрібні термінологічні системи, щоб не послуговуватися чужою мовою й не принижувати тим самим своєї національної гідності.

Актуальними напрямами подальшого розроблення окресленої проблеми є вивчення питань щодо взаємозв'язку фундаментальних та спеціальних дисциплін у формуванні мовленнєвої культури фахівців аграрного спрямування, розвиток мотивації студентської молоді до вдосконалення навичок професійного спілкування. 


\section{Література}

1. Бибрих Р. Р. Мотивационные аспекты адаптации студентов к учебному процессу в вузе / Р. Р. Бибрих // Психолого-педагогические аспекты адаптации студентов к учебному процессу. - Кишинев, 1990. - С. $17-29$. 2. Кияк Т. Р. Лингвистические аспекты терминоведения: [учебн. пособ.] / Т. Р. Кияк. - К. : УМКВО, 1989. 103 с. 3. Кочерган М. П. Вступ до мовознавтва: [підручник] / М. П. Кочерган. - К. : Академія, 2001. - 368 с. 4. Леонтьев А. А. Психология общения / А. А. Леонтьев. - М. : Смысл, 1997. - 365 с. 5. Тоцька Н. Методика роботи викладачів вищого технічного навчального закладу над українським професійним мовленням студентів / Н. Тоцька // Дивослово. - 2003. - № 1. - С. 62-65. 